\title{
Dividends and Foreign Performance Signaling
}

\author{
Robert Joliet* \\ IESEG School of Management, France \\ Aline Muller**,*** \\ University of Liège, Belgium
}

This study uses Hines' (1996) dividend process model to test the effect of domestic versus foreign profitability shocks on firms' dividend payout policy. Investigating an international sample of 283 companies from Continental Europe, Australia, New Zealand, the U.S.A. and Canada, we find that increases in some foreign market earnings stimulate higher cash distributions than similar increases in domestic earnings. The disaggregation of foreign performance across country-specific markets reveals that managers are predominantly using dividends to signal foreign profit movements that have been generated in emerging markets and Asian Pacific developed markets - while they do not feel compelled to send signals related to positive earnings news originating from other mature developed markets (i.e. North America and Western Europe). The findings also confirm the popular view that due to their higher variance and lower persistence, positive foreign profitability shocks coming from emerging markets are more difficult to integrate into stable dividend policies. (JEL : F23, M41, G14)

Keywords: disclosure, dividend policy, multinational firm, disaggregation, emerging markets

Article history: Received: 6 March 2013, Received in final revised form: 2 May 2014, Accepted: 27 May 2014, Available online: 13 May 2015

* IESEG School of Management (LEM-CNRS), Rue de la Digue 3, F-59000 Lille, France. E-mail: r.joliet@ieseg.fr.

** HEC Management School of the University of Liège, Ethias Chair in Asset and Risk Management, Liége - Belgium. *** LIFE Limburg Institute of Financial Economics, Maastricht University, The Netherlands.

(Multinational Finance Journal, 2015, vol. 19, no. 2, pp. 77-107)

(C) Multinational Finance Society, a nonprofit corporation. All rights reserved. DOI: $10.17578 / 19-2-1$ 


\section{Introduction}

In a world of rational expectations, in the absence of taxes, agency costs and informational asymmetries, dividend payout policies are value-irrelevant - dividends are exclusively determined by firms' current sources and uses statements. In a world where dividend and capital gain revenues are differentially taxed, however, we know that fiscal considerations may influence firms' payout behavior (Bernheim, 1991; Lie and Lie, 1999; Moser, 2007). On the other hand, dividends may be paid out when investors put higher prices on dividend-paying companies (Baker and Wurgler, 2004) or to alleviate agency costs by directly or indirectly reducing the financial discretion of managers (Easterbrook, 1984; Jensen 1986). Ultimately, if managers have valuable information, they may adjust firms' dividend behavior to signal information about the economic performance of the firm - particularly if the performance may be unobservable, inscrutable or enigmatic from the perspective of the investor (Bhattacharya, 1979, 1980; John and Williams, 1985; Miller and Rock, 1985; Ambarish, John and Williams, 1987).

Focusing on the signaling role of dividends it is commonly accepted from a theoretical perspective that the relationship between dividends and earnings should be positive. However many papers explore the relationship empirically and a definitive conclusion seems far to be reached (Watts, 1973; Healy and Palepu, 1988; Benartzi et al, 1997; Sant and Cowan, 1994; Arujo et al. 2011). While the debate is still ongoing it is puzzling to observe that the question whether dividends are differentially adjusted to domestic versus foreign earnings according to the country where these earnings have been generated hasn't received a lot of attention. Multinationals have been shown to pay overall higher dividends (Aggarwal and Aung Kyaw, 2010) and Hines (1996) showed that U.S. companies pay dividends out of their foreign profits at roughly three times the rate they do out of their domestic profits. However until now no study has attempted yet to explain managers' signaling strategy in response to increasing (decreasing) earnings generated in different foreign markets.

Given the tremendous increase in globalized trade and investment, as well as the resulting internationalization of companies, it is crucial to further explore to what extent earnings coming from various international markets have different stimulating effects on dividends. In other words, to what extent are managers differentially adapting their signaling strategy relative to domestic versus foreign profitability 
movements? From this particular perspective, the signaling theory of dividends triggers a highly interesting and challenging underlying research question: do foreign market characteristics affect managers' decision-making regarding dividend payouts? Two popular views may be questioned:

Do managers think that investors are unable to verify foreign earnings disclosures - suffering too much from informational asymmetries - and are managers hence putting more effort into signaling foreign performance through dividend payouts than they do into signaling domestic performance?

Are managers themselves questioning the persistence of some of their foreign earnings waves (originating, for instance, from 'risky' markets) - and are they hence reluctant to signal to their shareholders too much information coming from these markets?

In this paper, we answer these questions. The paper investigates in how far managers are using dividends to signal foreign performance relative to domestic performance. It explores the relationship between observed dividend payouts and foreign country-specific performance movements. ${ }^{1}$ Using a sample of 283 European, Canadian, Australian, New Zealand and U.S. dividend-paying companies with geographical segmented earnings disclosures, the paper is the first study exploring multinationals' detailed geographical information (i.e. foreign segmental profits) disclosures following the introduction of Statement of Financial Accounting Standards (SFAS) 131 - shedding herewith light on the influences of foreign country-specific earnings shocks on firms' dividend behavior. While Hines (1996) distinguishes between domestic and aggregate foreign earnings growth rates, we extend his work in two directions. First we investigate firms' foreign country-specific performance. These country-specific earnings disclosures enable us to examine how far managers are differentially signaling information coming from a large variety of countries - ranging from highly developed to emerging markets. Second, the international

1. According to Gelb (2000), from this perspective, firms that have to protect specific proprietary information from competitors tend to rely on dividend signals rather than on accounting disclosures to signal information. The structure and the nature of firms' foreign target markets play thus a crucial role in the determination of their dividend policy. Brav et al. (2005) find that dividends do convey information in general and need to be consistent with other forms of communication. 
sample enables us to compare the dividend policy responses across a wider diversity of international companies.

Empirical findings regarding the link between geographic segmented profitability movements and firms' payout behavior enable us to make four major contributions: (1) Overall, the positive relationship between foreign earnings changes and dividend movements is driven by performance changes seen in emerging and Asian Pacific developed markets. Managers are paying out a particularly high proportion of earnings accruals generated in these countries. (2) In contrast, managers do not feel compelled to signal information coming from their foreign operations in North American and Western European markets. Perhaps managers think that investors themselves are able to reliably verify earnings disclosures for these areas - no signal through dividend is actually needed. (3) Managers tend to avoid signaling performance movements generated in 'risky' markets. (4) And ultimately, dividend increases appear to signal favorable information about performance, while there is no evidence that dividend decreases contain any information about changes in profitability.

The outline of this paper is as follows. The next section introduces the motivation of the paper and formulates the hypotheses used to analyze the link between firms' dividend distribution behavior and domestic versus foreign performance movements. In section II, we describe the methodological framework and the selection procedure used to form the sample of multinational companies. Sample characteristics are carefully detailed. Section III estimates, analyzes and discusses how dividend payouts respond to foreign country-specific earnings shocks. Section IV concludes.

\section{Motivation}

For decades dividends have been at the heart of very active debates among academics and practitioners. Among the huge amount of academic and professional literature a significant amount of studies have been investigating the signaling role of cash distributions. Bar-Yosef and Huffman (1986) adapt the financial structure signaling model suggested by Ross (1977) to corporate dividend policies. The basic idea is that managerial compensation being intimately related to performance, if investors have imperfect information about the firm's profitability mangers' compensation system may provide an incentive to signal performance. According to the incentive-signaling argument, 
the amount of cash distribution should thus be an increasing function of expected cash flows - since managers are expected to use cash distributions to signal the performance of the company. ${ }^{2}$ In contrast with the widely held belief that future expected performance should be positively related to dividend payouts, empirical findings are mixed and puzzling. Penman (1983), Denis et al. (1994), Yoon and Starks (1995), Carroll (1995), Brook et al. (1998) and Nissim and Ziv (2001) report results consistent with Bar-Yosef and Huffman's (1986) signaling hypothesis. Dividend changes convey information about future earnings changes. Brook et al. (1998) also document evidence that dividend changes signal positive information about future cash flow levels, but they observe that the signaling plays a relatively minor role in corporate dividend policy. Yoon and Starks (1995) note that dividend increases are associated with subsequent significant increases in capital expenditures. On the other hand, Watts (1973), Riding (1984), DeAngelo et al. (1996) and Grullon et al. (2005) do not support the dividend signaling hypothesis. DeAngelo et al. (1996) suggest that managerial over-optimism about earnings prospects and modest cash commitments for dividend increases are undermining the reliability of dividend signaling. Grullon et al. (2005) observe that dividend growth rates are negatively correlated with future changes in profitability. On the other hand, Araujo et al. (2011) claim that the amount of cash dividends is a U-shaped function of future earnings due to an interaction between two opposite forces, investment and productivity. Benartzi et al. (1997) and Koch and Sun (2004) stress that dividends signal information about the persistence of past earnings changes rather than future earnings changes. These findings are in line with Hsu et al. (1998), who find that dividend movements are predominantly related to changes in permanent earnings. Finally, according to Mougout and Rao (2003), not all firms signal information through dividends. According to their results, only 20 percent of firms exhibit a temporal relationship between dividends and earnings.

Within this ongoing debate, the dramatically increasing fraction of profits generated by foreign operations opens challenging research questions. The analysis of the relationship between dividends and earnings coming from various international markets may indeed reveal

2. On the other hand, a study by Kalay (1980) shows that managers are reluctant to cut dividends since dividend reductions are more costly than dividend increases. Bar-Yosef and Huffman (1986) argue, furthermore, that managers sending false signals may be penalized. 
(a) whether according to the "informational content of dividends" hypothesis managers consider that they need to convey information more actively - through dividend payouts - about profit segments that are generated in foreign markets that are less familiar to investors; and/or (b) whether, in line with Benartzi et al. (1997), Hsu et al. (1998) and Koch and Sun (2004), managers are reluctant to signal profits originating from countries that may be considered as less stable because they are less confident in the persistence of these earnings.

\section{(a) the "informational content of dividends" hypothesis}

The disclosure of disaggregated earnings components enables investors to better understand earnings, to better forecast their evolution and thus to estimate firm value with a higher level of precision (Khurana et al., 2003). From a manager's perspective, disaggregated earnings may thus be an efficient tool to inform shareholders how the company and its management skills are performing in their different markets (Iatridis, 2008). From a regulatory point of view, most accounting practices require companies to report financial information on the performance of both their domestic and international activities. The introduction of Statement of Financial Accounting Standards (SFAS) 131 in the United States mandates companies to report financial information according to their geographic "operating segments". ${ }^{3}$ These "operating segments of a company shall be segregated to provide a better understanding of performance and a better assessment of its future cash flows, allowing users of financial statements to make a more informed judgment about a company as a whole". ${ }^{4}$ The informative role of disaggregated performance disclosures is thus embedded in SFAS 131. The regulator is obviously expecting managers to utilize these disclosures to provide additional information about the company and emphasizes that these disaggregated operating results "are (to be) regularly reviewed by the

3. SFAS No. 131 became effective for fiscal years beginning after December 15, 1997. We observe in the sample that, since 1997, the proportion of country-specific disclosures has increased, while the proportion of broader geographic area segment disclosures has decreased, consistent with the observations made by Nichols et al. (2000) and Herrmann and Thomas (2000).

4. Securities and Exchange Commission (SEC) RIN 3235-AH43 Segment Reporting. SFAS $\mathrm{N}^{\circ} 131$ superseded SFAS $\mathrm{N}^{\circ} 14$ in 1998 and established standards for reporting information about "operating segments" rather than following the "industry segments" standards that were in place previously. 
enterprise's chief operating decision maker to make decisions about resources to be allocated to the segment and assess its performance". 5 Obviously, on the one hand, the regulator's purpose is to help investors to better understand financial statements; on the other, he is emphasizing the importance of managers in their role of informing shareholders. ${ }^{6}$

Hope et al. (2009) show that geographically segmented reporting provides significant informational news to investors. ${ }^{7}$ Focusing on these disclosed foreign activities, Boatsman et al. (1993), Christophe (1997) and Christophe and Pfeiffer (2002) show, however, that investors do not value foreign operations as highly as they value domestic operations. In contrast, Bodnar and Weintrop (1997) and Bodnar et al. (2003) report that firm value is more strongly affected by changes in foreign earnings than by changes in domestic earnings. Given the undisputable difficulties in understanding geographical groupings, common cost allocations, intra-group transfers, inflation and exchange rate movements, authors unanimously agree that investors are faced with severe problems in interpreting this disaggregated performance information (Aggarwal and Aung Kyaw, 2010). Mispricing by markets of geographic segmented earnings information raises hence inevitably the question of whether managers do feel the need to use dividends to provide investors with additional, more comprehensible, signals regarding their foreign activities. This argument is in line with

5. Similar views and rules have been adopted in Canada, Australia, New Zealand and Europe. Like its U.S. counterpart, for instance, the Canadian Chartered Accountants of Canada (CICA) Handbook section 1701 mandates similar geographic segment disclosures. Likewise, the Australian Accounting Standard Board's AASB 1005 "Segment Reporting" aims to "facilitate the development of accounting standards that (...) allows users to make and evaluate decisions about allocating scarce resources (...), [and to be] relevant to assessing performance, financial position, financing and investment (...)". Furthermore, the Australian standard specifies that such segment reporting should "facilitate the Australian economy by reducing the cost of capital, enabling Australian entities to compete effectively overseas and having accounting standards that are clearly stated and easy to understand". Finally, international standard IAS 14 - predominantly used by European firms - imposes analogous rules for reporting financial information by geographical segment.

6. The link is particularly strong, since the U.S. Financial Accounting Standards Board (FASB) and other foreign accounting standards committees have required segments to be identified in coherence with the management's own view of them (Radebaugh et al., 2006).

7. Please refer e.g. to Iatridis (2010) for a detailed discussion on the way relevant accounting disclosures assist investors in forming informed and unbiased expectations about firms' future cash-flows. 
Brockman and Unlu's (2011) substitute hypothesis according to which more opaque environments, characterized by a lack of credible media (Travlos et al., 2001), lead to higher payouts because managers have stronger incentives to establish their reputation. On the other hand Brockman and Unlu's (2011) outcome hypothesis posits that more transparent environments lead to higher payouts because shareholder can more accurately measure (and hence demand) excess cash-flow.

\section{(b) the "persistence of earnings signaling" hypothesis}

Following Koch and Sun (2004) the "persistence of earnings signaling" hypothesis implies that managers increase cash dividend payouts to inform their shareholders that positive earning outcomes will not "reverse" in the future. The hypothesis is intimately linked to the concept of "permanent" vs "transitory" earnings - a decomposition of shocks in two fundamentally different parts that may not be regarded as equally value-relevant for investors (Ramakrishnan and Thomas, 1998).

According to several authors there are multiple reasons why foreign operations are expected to generate earnings that may be considered by investors as less "permanent" compared to domestic earnings. In comparison with domestic earnings, foreign earnings may for instance by characterized by an additional source of risk - exchange rate risk as they are affected by future exchange rate movements (Boatsman et al., 1993). Exchange rate volatility thus increases the variability and risk of the domestic currency denominated value of foreign earnings. Moreover given that investors may not be able to gather, analyze and accurately interpret all the information disclosed in foreign performance reports, one can presume that investors are more reluctant to interpret positive earnings outcomes as "permanent" increases. Duru and Reeb (2002) suggest that international diversification increases, moreover, the difficulty of forecasting earnings accurately because of the greater volatility of foreign earnings and the additional opportunities for managerial discretion - which in turn increases the information asymmetry between analysts and managers. Given the weaker informational properties of reported foreign earnings (compared to domestic earnings) investors may systematically underestimate the time persistence of reported international performance information (Thomas, 2000; Khurana et al., 2003; Callen et al., 2005) which may lead managers either to intentionally smooth foreign earnings to improve their informational content (Tuck and Zarowin, 2004) or to provide 
investors with more dividend-related signals to overcome this underestimation. On the other hand one may as well presume that following the prudence principle, in order to preserve the level of confidence of shareholders, managers feel reluctant to signal too much information related to earnings originating from countries that they consider too risky or generated by foreign operations that they consider too volatile.

\section{Methodological framework, sample selection and data description}

In this study, we adopt Hines' (1996) dividend process approach, which enters separately domestic and foreign earnings measures into the determination of dividend cash distributions. We would like to stress that in consistence with Benartzi et al. (1997), Hsu et al. (1998) and Koch and Sun (2004) we explore the relationship between dividend changes and current earning changes - and not the link between dividend changes and expectations about future earnings. This focus has strong implications in terms of time series of earnings. It implies that positive (negative) dividend changes are not necessarily followed by increasing (decreasing) earnings in the future. The sensitivity of firms' dividend behavior to foreign versus domestic performance changes is thus measured using the following model: ${ }^{8}$

$$
\Delta d_{i, t}=\gamma_{0}+\gamma_{1} \Delta E_{i, t}+\gamma_{2} \Delta F_{i, t}+\varepsilon_{i, t}
$$

where $\Delta d_{i, t}$ designates the change in firm $i$ 's dividend per share related to fiscal year $t, \Delta E_{i, t}$ the change in firm $i$ 's domestic profits during fiscal year $t$ and $\Delta F_{i, t}$ the change in firm $i$ 's foreign profits during fiscal year $t$.

8. As Hines (1996) noted, there is no consensus model of dividend payout behaviour. We put aside the possible disaggregated taxation issue, because sufficient data is not available at the firm and personal level. Since shareholders can have different tax status, and can be located anywhere in the world, they are subject to very different personal tax rates. We cannot use the personal taxation rate available within each cluster, since nothing guarantees that the extra cash generated in this cluster is paid out specifically to local shareholders.

Moreover, Amihud and Murgia (1997) interestingly find that the dividend changes are informative for reasons beyond taxation. Similarly, Brav et al. (2005) indicate that executives do not consider taxes as a dominant factor in their payout policy. 
In order to improve the empirical design suggested by Hines' study, to avoid some methodological weaknesses and to extend his work, we decided to enrich the methodology in five different ways. (i) First, due to their operations in different foreign countries, firms are confronted to extremely disparate economic environments, different costs, trading and investing barriers, political conditions and legal restrictions. The way the performance of foreign operations is perceived and interpreted is hence likely to be strongly disparate across geographic markets. It is for this reason that we disaggregate foreign earnings measures at the country-level and examine firms' dividend policies with respect to their foreign country-specific performance disclosures. (ii) As stressed by Grullon et al. (2005), dividend signaling theory does not indicate precisely what kind of performance metrics should be used. This study calibrates geographic segmented earnings to the firm's market value of equity. ${ }^{9}$ (iii) The investigations are performed on an international sample of U.S., Canadian, Australian, New Zealand and Continental European companies and are not restricted to U.S. firms. (iv) We distinguish between dividend increases and dividend decreases, since they may not convey identical signals (Nwaeze, 1998). We measure the dividend signal change by deflating changes in dividend per share by the stock price. As noted by Bernhardt et al. (2005), firms may be more focused on dividend levels than on dividend yields. ${ }^{10}$ (v) Finally, following related literature (see e.g. Boatsman et al., 1993; Bodnar and Weintrop, 1997), we control for intertemporal macroeconomic influences by including year dummies. As the sample firms are shown to be active in a large range of heterogeneous industry sectors, industry effects are similarly taken into account by the addition of sector dummies. Several robustness checks are also carried out.

In this paper, changes in foreign pre-tax operating earnings deflated by the firm's market value of equity are used as a measure of change in geographic segment profitability. ${ }^{11}$ We gather accounting segment data

9. We believe these performance measures to be intuitively more appropriate than previously used raw earnings measures.

10. As noted by Bernhardt et al. (2005), changes in dividend yield are largely driven by changes in the stock price.

11. Non-operating data are generally not available in geographic segment disclosures. Moreover, Grullon et al. (2005) highlight the fact that a measure of operating performance is preferable to other scaled-earnings variables, since it is sensitive neither to changes in capital structure nor to factors such as special items, accounting for minority interests and 
from the Thomson Reuters Worldscope database. ${ }^{12}$ For each individual company, we compute for each specific year from 1993 to 2006 geographic segmented annual profitability growth rates related to each specific disclosed country of operations. All values are denominated in firms' domestic currency. As changes in earnings have to be estimated, firm-year observations are included if and only if we observe at least two consecutive years of country-specific accounting data.

The selection procedure consists of several steps. The first one investigates all big and mid-capitalization firms being incorporated and geographically listed in one of the following indexes:

North America:

United States: S\&P 500 and S\&P 400

Canada: TSX

Continental Europe:

France: SBF 120

Germany: DAX 30, MDAX 50

The Netherlands: AEX,AMX

Asia Pacific:

Australia: ASX 200

New Zealand NZSX 40

Of these, only firms paying cash dividends are considered and financial services companies are excluded from the sample. ${ }^{13}$ When the same firm is included in several indexes, we keep it by country of domicile (e.g. a firm headquartered in Canada and cross-listed in the U.S. will be considered as Canadian and excluded from the U.S. firms sample). Subsequently, dividend-paying companies that are not internationalized (i.e. that do not report foreign activities in at least one foreign area) are eliminated. We are only interested in firms disclosing sufficiently detailed geographical segmental information (i.e. foreign segmental profits). Consistent with the current literature (Boatsman et al., 1993; Thomas, 2000; Christophe and Pfeiffer, 2002), companies that

income taxes.

12. We consider exclusively data as originally reported, not as subsequently restated.

13. Following Bodnar et al. (2003), financial services companies are deleted from the sample as their foreign revenues disclosures are not analogous to the disclosures of non-financial firms that prevail in the sample. 
aggregate foreign operations into a single disclosure labeled "international" or "foreign" are excluded. Thus, we did not select stock indexes from some developed countries (such as, for instance, Spain, Italy, Switzerland and Japan), since firms included in these indexes do not usually disclose precise geographic earnings data. British indexes were also excluded from the sample because of the get-out clause provided in the accounting standard SSAP 25 . When the firm considers the disclosure of segment information to be seriously prejudicial to its interests, it does not have to disclose it. This leads to inconsistencies in the geographic segments reported by most companies (Aleksanyan and Danbolt 2005). The entire procedure yields a total sample of 283 multinational firms, sorted into eight different industry sectors. ${ }^{14}$ The 283 firms of the final sample have their registered offices in Continental Europe (38), the United States and Canada (191), and Australia and New Zealand (54).

The sample period ranges from 1993 to 2006 . We intentionally exclude the crisis period starting in $2007 .{ }^{15}$ On the one hand, Fuller and Goldstein (2011) and Bozos et al. (2011) argue that the value-relevance of dividends changes in crisis markets. Given that we aim to investigate the signaling of dividends across different sources of earnings we need to avoid time-variation in the overall informational content of dividends - generated for instance by the inclusion of a crisis period. On the other hand, the adverse economic conditions of the crisis caused major negative shocks to the supply of external capital as well as significant negative shifts in the outlook for corporate profitability. The impact of the crisis on firms' financial constraints as well on firms' earnings properties (qualities) have been shown to be strongly differential with respect to firms' age, size and industry for instance (Duchin et al., 2010). While the influences of these differential exposures should be explored in the future, they lie beyond the scope of this study and may

14. These industry sectors are: consumer cyclical, consumer non cyclical, energy, healthcare, industrials, materials, technology, and utilities.

15. To check the rationale of excluding the crisis period from the sample, we performed the analysis as well on the sample period ranging from 1993 to 2010 and estimated the regressions by including dummy variables for the crisis period (i.e. from 2007 to 2010). As expected, empirical evidence weakens and is somewhat confusing during the crisis period. In line with the current literature (Fuller and Goldstein, 2011; Bozos et al., 2011; Duchin et al., 2010) the findings support hence that the value-relevance of dividends is particularly difficult to disentangle and interpret during crisis periods. Results are described in table 5 and discussed at the end of section 3 devoted to robustness checks. 
bias the analysis of the impact of the origin of earnings on managers' signaling strategy.

We use two levels of foreign performance disclosure. First, we add up the country-specific foreign performance disclosures into an aggregate measure of foreign performance. For each individual company, this performance is measured by summing all operating incomes generated in foreign countries. Second, we explore country-specific disclosures as they are reported in companies' financial statements. ${ }^{16}$ Firms' country-specific performance information is quantified for each particular foreign country of operations as the sum of all operating incomes generated in that foreign country divided by the company's total foreign assets in that country.

The dependent variable of the analysis is based on the dividend per share. First, firms' fiscal year end dates are verified in order to relate each dividend payment to the appropriate fiscal year. Differences across countries are observed in terms of payment periodicity. American and Canadian firms' dividends are usually paid quarterly. European firms' dividends tend to be paid yearly, a few months after the end of the firm's fiscal year, whereas Australasian firms' dividends are generally paid half-yearly. One interim dividend is paid during the fiscal year and a second dividend is paid one or two months after the end of the firm's fiscal year. For U.S. and Canadian companies, we decided to add up the four quarterly dividends paid during the fiscal year in order to obtain annual dividends related to fiscal years. Likewise for Australasian companies, we sum both dividends to obtain annual dividends. Although it is common for Dutch firms to pay dividends only once a year, a few companies pay interim dividends. In that case, we also consider the total dividend payments over the fiscal year. Furthermore, dividends per share have been adjusted for stock splits and are denominated in each firm's domestic currency. All these data observations are obtained from Thomson Financial Datastream International. ${ }^{17}$ It should be emphasized that these measurement

16. The increasing percentage of companies providing country-specific disclosures of their foreign operations enables us to investigate the value-relevance of these detailed foreign performance disclosures. Countries included are: France, Germany, Ireland, Spain and the UK in Europe, Canada and the USA in Northern America, Argentina, Brazil, Chile, Ecuador and Mexico in Latin America, South Africa in Africa, and China, Hong-Kong, Japan, Korea, Yemen, Australia, Indonesia, New Zealand and Papua New Guinea in Asia Pacific.

17. We consider exclusively the listing information in the firms' country of incorporation. If a company is also listed on foreign exchanges, these listings are ignored in the study. 


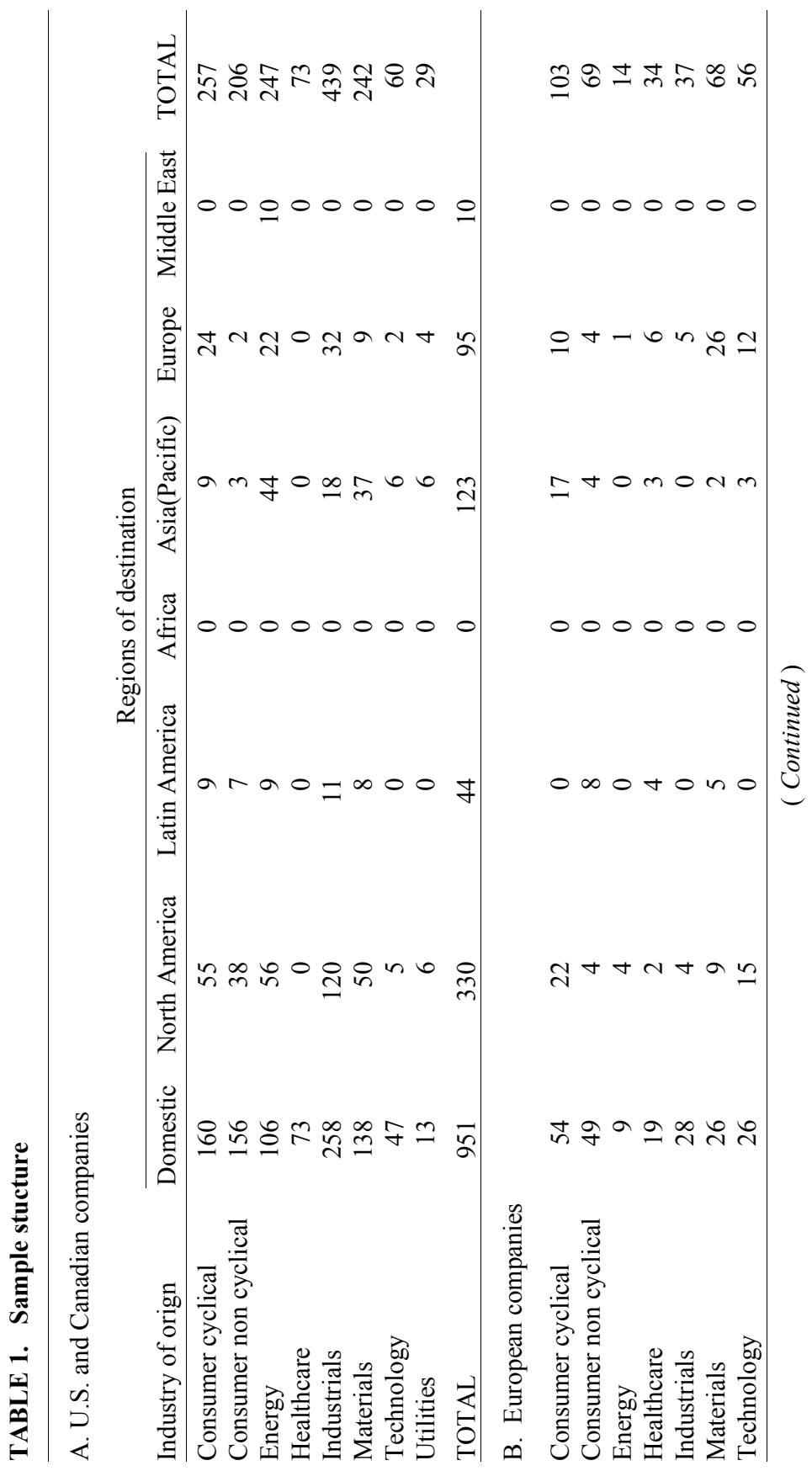


Dividends and Foreign Performance Signaling

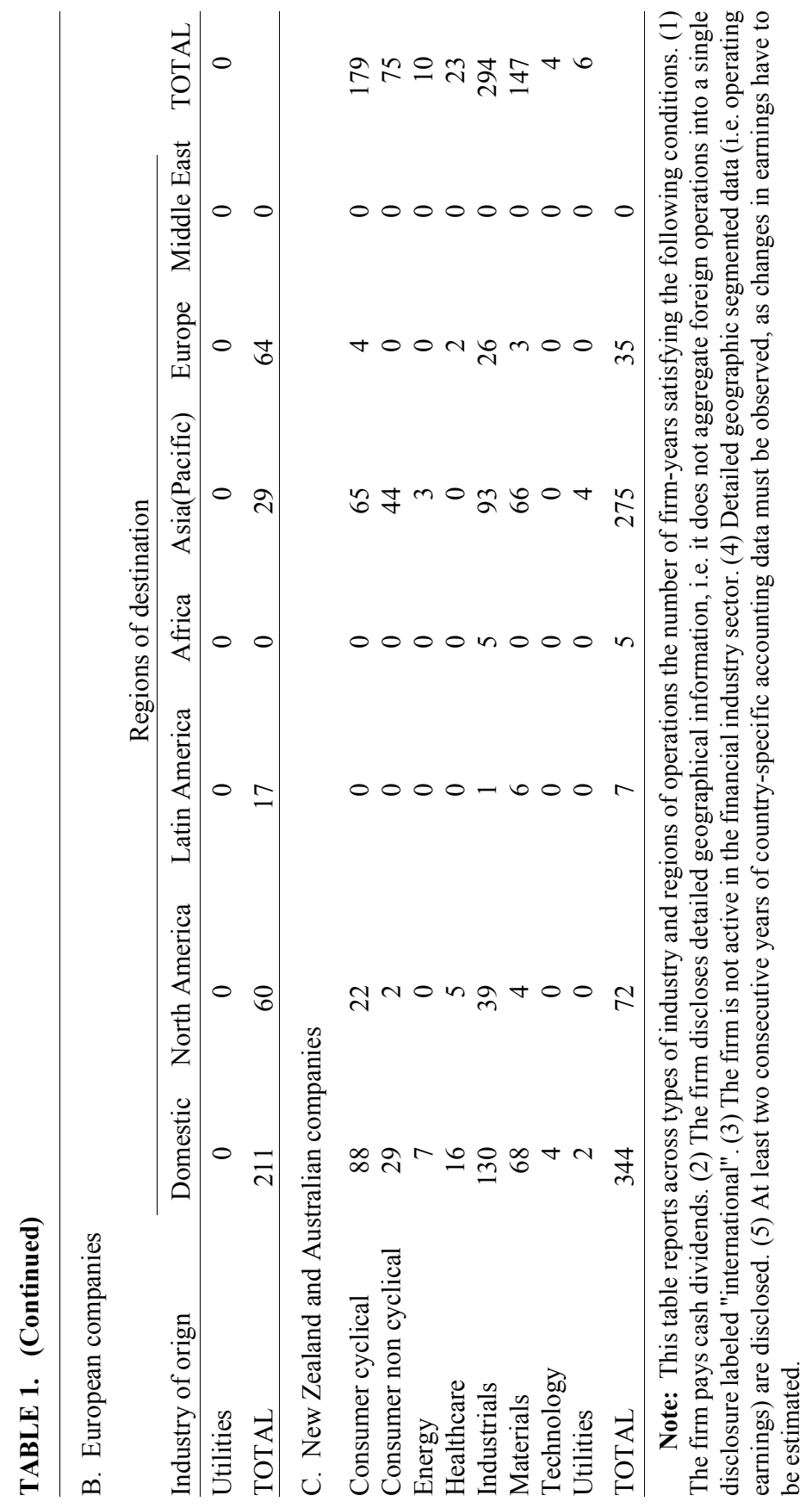


TABLE 2. Mean dividend yields and dividend payout ratios per country of origin - sample period 1993-2006 excluding the crisis period

A. Total sample

\begin{tabular}{lccc} 
Countries of origin & & Dividend yield(\%) & $\begin{array}{c}\text { Dividend } \\
\text { Payout ratio (\%) }\end{array}$ \\
\hline All (283 companies) & Mean & $2.5909 \%$ & $37.1621 \%$ \\
& Std. Dev. & $1.8821 \%$ & $41.8732 \%$ \\
\hline B. Sub-samples & & & \\
$\begin{array}{l}\text { U.S. and Canada } \\
\text { (191 companies) }\end{array}$ & Mean & $2.0367 \%$ & $31.5277 \%$ \\
$\begin{array}{l}\text { France, Germany, } \\
\text { the Netherlands(38 }\end{array}$ & Std. Dev. & $1.4459 \%$ & $48.6478 \%$ \\
$\begin{array}{l}\text { companies) } \\
\text { New-Zealand and }\end{array}$ & Std. Dev. & $2.2846 \%$ & $35.6651 \%$ \\
$\begin{array}{l}\text { Australia(54 } \\
\text { companies) }\end{array}$ & Mean & $1.3709 \%$ & $19.7945 \%$ \\
\hline
\end{tabular}

Note: Panel A of this table reports the mean statistics for the dividend yield and the dividend payout ratio for all sample firm-year observations. Panel B of this table reports across countries of origin the mean statistics for the dividend yield and the dividend payout ratio.

procedures are performed according to each firm's specific fiscal year end (firms' fiscal years end on different specific dates and not necessarily on December $31^{\text {st }}$ ). The time period used to calculate dividend policy measures is hence based on each individual company's accounting data release. This is in sharp contrast with previous studies (Boatsman et al., 1993; Thomas, 2000; Christophe, 2002), which usually limit their sample to firms with December fiscal year ends.

The breakdown of the sample across industry sector, country of origin and geographic location of foreign operations is reported in table 1. While approximately half of U.S. (respectively Canadian) companies are (or have been) operating in Canada (respectively the U.S.), less than 20 percent of those are active in Europe and/or in Asia. These firms are predominantly operating in the energy, materials and industrial sectors. On the other hand, 8 out of 38 European companies disclose country-specific information regarding operations in Asia and/or North America - most of them being active in the consumer cyclical sector. Obviously, Asia (Pacific) constitutes the major geographic destination for which foreign activities are disclosed in the financial statements of Australian firms. This is not surprising, given that Australia has close ties with neighboring Asian countries. Overall, geographically close 
countries often represent the first disclosed destination and industrial companies are most represented among the North American and Australian sample, while European multinationals are primarily active in the consumer sector.

Table 2 describes average dividend yields and dividend payout ratios across the total sample as well as across country of origin. Clearly, Australian and New Zealand firms differ from the rest of the sample. They exhibit dividend yields that are twice as high as those of North American or European firms and report, on average, the highest payout ratios $(53.6 \%$ against $31.5 \%$ and $35.7 \%)$. The difference may be attributed to the Australian tax system, which favors dividends over capital gains (Ho, 2003). Regarding the rest of the sample, mean payout ratios are quite similar between Europe and North America, which is in line with Von Eije and Megginson (2008), who find that dividend policies of EU companies are similar in many ways to those of American firms. However, we observe that dividend policies are particularly heterogeneous among North American companies.

\section{Empirical findings}

Following the empirical design described in section I, we estimate a firm's dividend policy sensitivity to domestic versus aggregate foreign earnings shocks using the following model:

$$
\begin{gathered}
\frac{\Delta D_{i, t}}{P_{i, t-1}}=\sum_{p}^{7} \chi_{i p} \text { Industry }_{p}+\sum_{t}^{13} \mu_{t} \text { Year }_{t}+\gamma_{1} \frac{\Delta D E_{i, t}}{M V_{i, t-1}}+ \\
\gamma_{2} \frac{\Delta F E_{i, t}}{M V_{i, t-1}}+\varepsilon_{i, t}
\end{gathered}
$$

where $\Delta D_{i, t}$ is the change in firm i's dividend per share from fiscal year $t-1$ to fiscal year $t, P_{i, t-1}$ is the stock price at the end of the fiscal year $t-1$. Industry refers to sector dummies equal to one for the proper industry of firm $i$ and zero otherwise. Year refers to the year dummies equal to one for the corresponding year $t$ and zero otherwise. $\Delta D E_{i, t}$ is the change in domestic earnings, defined as the change in operating earnings generated in firm $i$ 's home country from fiscal year $t-1$ to fiscal year $t . \Delta F E_{i, t}$ is the change in foreign earnings, defined as the change in firm $i$ 's aggregated operating earnings from foreign areas 
TABLE 3. Firm-level cash distribution reaction to domestic versus foreign earnings movements - sample period 1993-2006 excluding the crisis period

\begin{tabular}{|c|c|c|c|c|c|c|}
\hline Countries of origin & & $\begin{array}{l}\text { Change in } \\
\text { domestic } \\
\text { earnings }\end{array}$ & $\begin{array}{l}\text { Change in } \\
\text { foreign } \\
\text { earnings }\end{array}$ & $\operatorname{adj} . R^{2}$ & F-star & $\begin{array}{l}\text { Wald test } \\
\text { equality } \\
\text { (signif.) }\end{array}$ \\
\hline $\begin{array}{l}\text { U.S. and Canada } \\
\text { (191 companies) }\end{array}$ & $\begin{array}{l}\text { Coefficient } \\
\text { Std. Dev. }\end{array}$ & $\begin{array}{l}0.0023 \\
0.0072\end{array}$ & $\begin{array}{r}-0.0019 \\
0.0071\end{array}$ & 4.0 & $\begin{array}{c}2.95 \\
(0.00)\end{array}$ & $\begin{array}{c}0.14 \\
(0.70)\end{array}$ \\
\hline $\begin{array}{l}\text { France,Germany, } \\
\text { the Netherlands } \\
\text { (38 companies) }\end{array}$ & $\begin{array}{l}\text { Coefficient } \\
\text { Std. Dev. }\end{array}$ & $\begin{array}{l}0.0147 \\
0.0104\end{array}$ & $\begin{array}{l}0.0062 \\
0.0099\end{array}$ & 6.1 & $\begin{array}{c}1.67 \\
(0.04)\end{array}$ & $\begin{array}{c}0.26 \\
(0.61)\end{array}$ \\
\hline $\begin{array}{l}\text { New-Zealand and } \\
\text { Australia } \\
\text { ( } 54 \text { companies) }\end{array}$ & $\begin{array}{l}\text { Coefficient } \\
\text { Std. Dev. }\end{array}$ & $\begin{array}{l}0.0951 * * * \\
0.0220\end{array}$ & $\begin{array}{l}0.0389 * * * \\
0.0186\end{array}$ & 14.2 & $\begin{array}{l}3.7 \\
(0.00)\end{array}$ & $\begin{array}{c}4.31 \\
(0.04)\end{array}$ \\
\hline
\end{tabular}

Note: This table reports across countries of origin the impact of disclosed changes in domestic versus foreign earnings on changes in firms' dividends per share. The following model is used:

$$
\frac{\Delta D_{i, t}}{P_{i, t-1}}=\sum_{p}^{7} \chi_{i p} \text { Industry }_{p}+\sum_{t}^{13} \mu_{t} \text { Year }_{t}+\gamma_{1} \frac{\Delta D E_{i, t}}{M V_{i, t-1}}+\gamma_{2} \frac{\Delta F E_{i, t}}{M V_{i, t-1}}+\varepsilon_{i, t}
$$

where $\Delta D_{i, t}$ is the change in firm $i$ 's dividend per share from fiscal year $t-1$ to fiscal year $t$, $P_{i, t-1}$ is firm $i$ 's stock price at the end of the fiscal year $t-1$, Industry refers to sector dummies equal to one for the proper industry of firm $i$, zero otherwise. Year refers to the year dummies equal to one for the corresponding year $t$ and zero otherwise. $\Delta D E_{i, t}$ is the change in domestic earnings, defined as the change in operating earnings generated in firm $i$ 's home country, from fiscal year $t-1$ to fiscal year $t . \Delta F E_{i, t}$ is the change in foreign earnings, defined as the change in firm $i$ 's aggregated operating earnings from foreign areas, from fiscal year $t-1$ to fiscal year $t . M V_{i, t-1}$ is the market value of firm $i$ at the end of firm $i$ 's fiscal year $t-1$. The F-stat is a test of the null hypothesis that the earnings coefficients are equal to zero. P-values are provided in parentheses. Wald tests for equality of both domestic and foreign coefficients are provided with the $\mathrm{p}$-value in parentheses. ${ }^{*}, * * * * *$ indicate that the estimated coefficients are statistically different from zero at the $10 \%, 5 \%$ and $1 \%$ level respectively. White's (1980) heteroskedasticity-consistent standard errors are also exhibited.

from fiscal year $t-1$ to fiscal year $t . M V_{i, t-1}$ is the market value of the firm at the end of the fiscal year $t-1$.

Results are reported in table 3 and differentiated according to the country of origin of each individual firm. The major difference observed between both North American and European firms and Australian firms is the impact of earnings movements. For North American firms and European firms, no significant effect is found for either domestic or aggregate foreign earnings. On the other hand, the dividend policy response for both domestic and foreign earnings is positive and 
significant for Australian firms. In addition, we can reject the equality of the two coefficients at the $5 \%$ level.

In order to verify whether foreign performance movements generated in different types of countries affect differentially firms' dividend policies, we estimate the following pooled model:

$$
\begin{aligned}
\frac{\Delta D_{i, t}}{P_{i, t}}= & \sum_{u}^{6} \text { Country }_{u}+\sum_{p}^{7} \varsigma_{i p} \text { Industry }_{p}+\sum_{t}^{13} \xi_{t} \text { Year }_{t}+ \\
& \lambda_{1} \frac{\Delta D E_{i, t}}{M V_{i, t-1}}+\sum_{j=1}^{s} \lambda_{j+1} \frac{\Delta F E_{i j, t}}{M V_{i, t-1}}+\varepsilon_{i, t}
\end{aligned}
$$

where $\Delta D_{i, t}$ is the change in firm $i$ 's dividend per share from fiscal year $t-1$ to fiscal year $t, P_{i, t-1}$ is firm $i$ 's stock price at the end of the fiscal year $t-1$. Country refers to country dummies equal to one for the country of origin of firm $i$ and zero otherwise. ${ }^{18}$ Industry refers to sector dummies equal to one for the industry of firm $i$, zero otherwise. Year refers to year dummies equal to one for the corresponding year $t$ and zero otherwise. $\Delta D E_{i, t}$ is the change in domestic earnings, defined as the change in operating earnings generated in firm $i$ 's home country from fiscal year $t-1$ to fiscal year $t . \Delta F E_{i j, t}$ is the change in specific foreign earnings generated in country $j$, defined as the change in operating earnings generated by firm $i$ in country $j$ from fiscal year $t-1$ to fiscal year $t . M V_{i, t-1}$ is the market value of firm $i$ at the end of firm $i$ 's fiscal year $t-1$. Following the extant literature (Benartzi et al., 1997; Nissim and Ziv, 2001; Koch and Sun, 2004 and Grullon et al., 2005), a further precaution to take is to distinguish between positive and negative dividend changes (i.e. dividend increases versus dividend decreases). Previous evidence suggests that dividend increases and dividend decreases may contain neither similar nor symmetric information.

In table 4 (Panel A), we observe that domestic changes in earnings exhibit statistically significant positive response coefficients for dividend increases, while aggregate foreign earnings movements have no statically significant impact on dividend payouts. These results suggest that managers translate exclusively positive domestic performance changes into increased dividends. Apparently, neither

18. Since significant differences in dividend policies are observed in terms of volume, it is hence important to include country of origin dummies. 
TABLE 4. Firm-level cash distribution reaction to domestic versus foreign country-specific earnings movements - sample period 1993-2006 excluding the crisis period

A. Domestic versus foreign performance disclosures

\begin{tabular}{lcc} 
Disclosed changes in earnings & Coefficient & Std. Error \\
\hline Dividend increases $(n=1,027)$ & & \\
\hline Domestic & $0.0217^{* *}$ & 0.0095 \\
Foreign & 0.0058 & 0.0048 \\
adj. $\mathrm{R}^{2}$ & 14.3 & \\
F-stat & 7.55 & $(0.00)$ \\
Wald test & 1.96 & $(0.16)$ \\
\hline Dividend decreases $(n=122)$ & & \\
\hline Domestic & 0.0216 & 0.0138 \\
Foreign & -0.0036 & 0.0131 \\
adj. $\mathrm{R}^{2}$ & 16.9 & \\
F-stat & 1.96 & $(0.01)$ \\
Wald test & 1.63 & $(0.20)$
\end{tabular}

B. Domestic versus foreign country-specific performance disclosures

Dividend increases $(n=1,027)$

\begin{tabular}{|c|c|c|}
\hline Domestic & $0.0142 * *$ & 0.0058 \\
\hline \multicolumn{3}{|c|}{ France, Germany, Ireland, Spain, UK, } \\
\hline USA, Canada & 0.0082 & 0.0088 \\
\hline Japan, Australia, New Zealand & $0.2222 * * *$ & 0.0618 \\
\hline \multicolumn{3}{|c|}{ Mexico, Argentina, Brazil, Chile, Ecuador, } \\
\hline \multicolumn{3}{|c|}{ China, Hong Kong, Korea, Yemen, Indonesia, } \\
\hline $\operatorname{adj} . R^{2}$ & 19.1 & \\
\hline F-stat & 9.6 & $(0.00)$ \\
\hline Wald test & 20.8 & $(0.00)$ \\
\hline \multicolumn{3}{|l|}{ Dividend decreases $(n=122)$} \\
\hline Domestic & 0.0211 & 0.0148 \\
\hline \multicolumn{3}{|c|}{ France, Germany, Ireland, Spain, UK, } \\
\hline USA, Canada & 0.0376 & 0.0445 \\
\hline Japan, Australia, New Zealand & -0.2973 & 0.4373 \\
\hline \multicolumn{3}{|c|}{ Mexico, Argentina, Brazil, Chile, Ecuador, } \\
\hline \multicolumn{3}{|c|}{ China, Hong Kong, Korea, Yemen, Indonesia, } \\
\hline Papua New Guinea & -0.2553 & 0.3808 \\
\hline $\operatorname{adj} . R^{2}$ & 16.7 & \\
\hline F-stat & 1.8 & $(0.02)$ \\
\hline Wald test & 1.0 & $(0.79)$ \\
\hline
\end{tabular}

( Continued) 
TABLE 4. (Continued)

Note: This table reports how disclosed changes in domestic, aggregated foreign and foreign country-specific earnings movements are affecting firms' changes in dividends per share. The table distinguishes between dividend increases and dividend decreases. The following model is used:

$$
\begin{gathered}
\frac{\Delta D_{i, t}}{P_{i, t-1}}=\sum_{u}^{7} \zeta_{i u} \text { Country }_{u}+\sum_{p}^{7} \varsigma_{i p} \text { Industry }_{p}+\sum_{t}^{13} \xi_{t} \text { Year }_{t}+ \\
\lambda_{1} \frac{\Delta D E_{i, t}}{M V_{i, t-1}}+\sum_{j=1}^{s} \lambda_{j+1} \frac{\Delta F S E_{i j, t}}{M V_{i, t-1}}+\varepsilon_{i, t}
\end{gathered}
$$

where $\Delta D_{i, t}$ is the change in firm $i$ 's dividend per share from fiscal year $t-1$ to fiscal year $t$, $P_{i, t-1}$ is firm $i$ 's stock price at the end of the fiscal year $t-1$, Country refers to country of origin dummies equal to one for the proper country of origin of firm $i$, zero otherwise, Industry refers to sector dummies equal to one for the proper industry of firm $i$, zero otherwise, Year refers to the year dummies equal to one for the corresponding year $t$ and zero otherwise. $\Delta D E_{i, t}$ is the change in domestic earnings, defined as the change in operating earnings generated in firm $i$ 's home country, from fiscal year $t-1$ to fiscal year $t . \Delta F S E_{i j, t}$ is the change in specific foreign earnings generated in country $j$, defined as the change in operating earnings generated by firm $i$ in country $j$, from fiscal year $t-1$ to fiscal year $t . M V_{i, t-1}$ is the market value of firm $i$ at the end of firm $i$ 's fiscal year $t-1$. The F-stat is a test of the null hypothesis that the earnings coefficients are equal to zero. P-values are provided in parentheses. Wald tests for equality of both domestic and foreign coefficients are provided with the p-value in parentheses.In Panel B, geographic clusters are then formed for countries exhibiting similar effects on dividend changes, for which we do not find statistically different coefficients at the $10 \%$ level.*, $* *, * * *$ indicate that the estimated coefficients are statistically different from zero at the $10 \%, 5 \%$ and $1 \%$ level respectively. White's (1980) heteroskedasticity-consistent standard errors are also exhibited.

positive nor negative movements in aggregate foreign profits lead managers to modify their dividend policy.

The disaggregation of foreign earnings into country-specific earnings sheds new light on the effect of foreign earnings movements on dividend policies (Panel B). First of all, dividend increases appear to be connected to favorable information about domestic and foreign performance. ${ }^{19}$ The results are consistent with Hines (1996), who finds that firms pay dividends at high rates out of their profits generated in some specific foreign markets. The discrepancies in country-specific

19. Still there is no statistically significant evidence that dividend decreases contain information about changes in earnings. 
responses (Panel B) explain, moreover, why the coefficients associated with the aggregated foreign earnings are insignificant (Panel A). Results in Panel B of table 4 report that good performance news originating from developed countries such as France, Germany, the UK, the USA or Canada does not affect firms' dividend payouts. It seems that managers do not feel compelled to signal performance coming from these mature markets. They may think that investors themselves are able to reliably verify earnings disclosures originating from these countries - no dividend signal is hence needed to inform investors. ${ }^{20}$ On the other hand, managers appear to feel the necessity to signal good performance generated in less mature foreign markets, thus supporting Hines' (1996) signaling view. Both Latin American (e.g. Mexico) and emerging Asian countries (e.g. Indonesia) may be grouped together, since we do not find any significant differences in the corresponding response coefficients. ${ }^{21}$ As profits generated in these countries are difficult to verify for investors, positive movements in these profits need to be communicated through dividend payouts. It is, however, interesting to observe that good news from the Asian Pacific region (e.g. Japan, Australia, New Zealand) leads to exceptionally high and comparatively stronger increases in dividends. ${ }^{22}$ Indeed, the effect is statistically stronger for the Asian Pacific region than for emerging countries or for the domestic market (Chi-square $=20.85, \mathrm{p}$-value $=0.00$ ). These outcomes suggest that whereas managers feel the need to signal good performance from emerging markets, they are nevertheless reluctant to strongly signal earnings from countries that are believed to generate erratic income respectively markets for which earnings forecasting is more difficult. These results are consistent with Benartzi et al. (1997), Hsu et al. (1998) and Koch and Sun (2004), who argue that dividend changes are more likely to be related to changes in permanent earnings. Managers may consider that positive performance changes generated in emerging markets are not as permanent as earnings news originating from Japan,

20. For comparability, we present in Panel B of table 4 similar country clustering for dividend decreases, although, of course, no country exhibits a significant response in any case.

21. For the null hypothesis of equality of the coefficients associated with Latin American countries vs. emerging Asian countries: Chi-squared $=0.863$, p-value $=0.35$. All specific-country Wald tests, inside within clustered areas, are also available upon request.

22. We cannot reject the null hypothesis of equality of response coefficients between news coming from Japan, Australia or New Zealand (Chi-squared=3.31, p-value $=0.19$ ). 


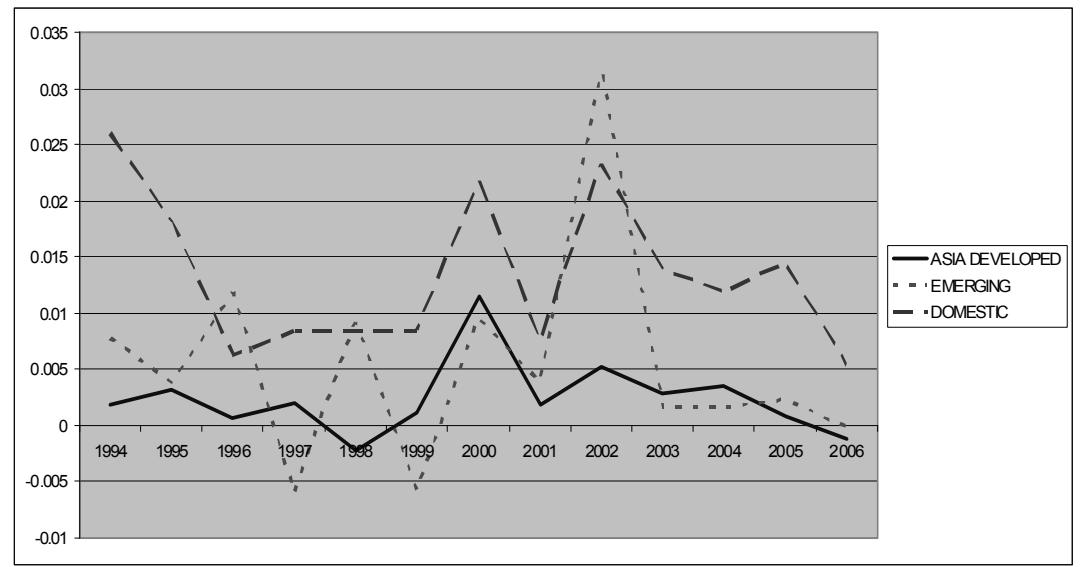

FIGURE 1.- Changes in disclosed domestic earnings, Asian Pacific developed markets earnings and foreign emerging markets earnings

Note: This figure plots the temporal evolution of the annual mean changes in disclosed domestic earnings (dashed line), Asian Pacific developed markets earnings (solid line) and foreign emerging markets earnings (dotted line). All changes in earnings are deflated by the corresponding market value of the firm at the beginning of each period. Asian Pacific developed markets encompass specific disclosures for Japan, Australia and New Zealand. Foreign emerging markets encompass specific disclosures for Latin American countries (Mexico, Argentina, Brazil, Chile, Ecuador) and Asian emerging countries (China, Hong Kong, Korea, Yemen, Indonesia, and Papua New Guinea).

Australia or New Zealand. They may, moreover, fear that investors distrust signals related to performance news coming from risky emerging markets. Conversely, earnings increases in less risky Asian markets - perceived as more predictable markets - lead to particularly high and significant increases in dividends per share.

The popular view that Japan, Australia and New Zealand are characterized on average by more stable and hence more reliable economic performance can be empirically verified for the sample in figure 1. The figure plots the temporal evolution of changes in earnings during the entire sample period across Asian Pacific developed markets (solid line), foreign emerging markets (dotted line) earnings and the domestic market (dashed line) - deflated by the corresponding market value of the firm at the beginning of each period. Clearly, changes in earnings generated in emerging markets are more volatile and 
unpredictable than changes in earnings in Asian Pacific less risky markets. The contagious negative effects of the Asian financial crisis in 1997 and the Brazilian crisis in 1999 on the performance generated in emerging markets are particularly noteworthy. The empirical link between dividend payouts and foreign performance movements generated in emerging markets is thus coherent with Bar-Yosef and Huffman's (1986) model suggesting a theoretical negative connection between dividend payment and risk exposure. The negative association between dividend changes and future earnings variance is empirically documented by Eades (1982) and Caroll (1995). Typically, while managers feel the need to signal performance that is not easily verifiable by investors, the higher the riskiness of the performance, the more managers are reluctant to strongly signal this performance.

Some robustness checks are performed. Table 5 describes the relationship between country-specific earnings and dividend increases vs. decreases when the crisis period (2007-2010) is included in the sample period. As expected (Fuller and Goldstein, 2011; Bozos et al., 2011; Duchin et al., 2010) the inclusion of a period in which companies have been forced to adapt quite abruptly their dividend strategy to external conditions influences the findings. Overall the significance of estimates weakens and evidence becomes less conclusive. The main reason explaining these mixed results is that findings during the crisis period are distorted by some companies' dividend policy changes that cannot be linked to current-profitability-related arguments. Additional robustness checks include the deflation of dividend changesbystockprices, whereby we deflate dividend change by theprior-yeard dividend per share (Benartzi et al., 1997; Nissim and Ziv, 2001; Koch and Sun, 2004; Grullon et al., 2005). We also allow some lags in the deflator of the dividend per share and earnings changes over 3 months. The conclusions remain unaffected.

The effect of taxation on dividend payout ratios in each country may be significant and obviously different according to the tax system. More specifically, the impact in terms of dividend tax system types may influence the magnitude of dividend changes.If dividends are "double taxed" (first at the corporate level and then at the personal level), we expect a slower adjustment to target dividends and more moderate dividend payouts (Alzahrani and Lasfer 2009). Similarly, differential tax rates on capital gains vs. dividends may as well induce changes in dividend policies. An in-depth analysis of the impact of taxation is nevertheless beyond the scope of this paper. 
TABLE 5. Firm-level cash distribution reaction to domestic versus foreign country-specific earnings movements - sample period 1993-2010 including the crisis period

\begin{tabular}{|c|c|c|}
\hline Disclosed changes in earnings & Coefficient & Std. Error \\
\hline \multicolumn{3}{|l|}{ Dividend increases $(n=1,128)$} \\
\hline Domestic & $0.0212 * *$ & 0.0093 \\
\hline Domestic (crisis) & 0.0171 & 0.0271 \\
\hline \multicolumn{3}{|l|}{ France, Germany, Ireland, Spain, UK, } \\
\hline \multicolumn{3}{|l|}{ France, Germany, Ireland, Spain, UK, } \\
\hline USA, Canada (crisis) & -0.0291 & 0.0301 \\
\hline Japan, Australia, New Zealand & $0.1176^{* *}$ & 0.0608 \\
\hline Japan, Australia, New Zealand (crisis) & $1.7644 * * *$ & 0.6640 \\
\hline \multicolumn{3}{|c|}{ Mexico, Argentina, Brazil, Chile, Ecuador, } \\
\hline $\begin{array}{l}\text { China, Hong Kong,Korea, Yemen, Ind } \\
\text { Papua New Guinea }\end{array}$ & $0.0646 * * *$ & 0.0152 \\
\hline \multicolumn{3}{|c|}{ Mexico, Argentina, Brazil, Chile, Ecuador, } \\
\hline \multicolumn{3}{|c|}{ China, Hong Kong, Korea, Yemen, Indonesia, } \\
\hline Papua New Guinea (crisis) & -0.0580 & 0.1146 \\
\hline Adj. $\mathrm{R}^{2}$ & 17.7 & \\
\hline F-stat & 28.7 & $(0.00)$ \\
\hline Wald-test & 39.4 & $(0.00)$ \\
\hline \multicolumn{3}{|l|}{ Dividend decreases $(n=149)$} \\
\hline Domestic & $0.0455^{*}$ & 0.0249 \\
\hline Domestic (crisis) & $-0.1492 * *$ & 0.0663 \\
\hline \multicolumn{2}{|l|}{ France, Germany, Ireland, Spain, UK, } & 0.0206 \\
\hline \multicolumn{3}{|l|}{ France, Germany, Ireland, Spain, UK, } \\
\hline USA, Canada (crisis) & -0.3632 & 0.2437 \\
\hline Japan, Australia, New Zealand & -0.2932 & 0.4864 \\
\hline Japan, Australia, New Zealand (crisis) & 0.3387 & 0.6930 \\
\hline \multicolumn{3}{|l|}{ Mexico, Argentina, Brazil, Chile, Ecuador, } \\
\hline \multicolumn{3}{|c|}{ China, Hong Kong, Korea, Yemen, Indonesia, } \\
\hline Papua New Guinea & -0.3829 & 0.4687 \\
\hline \multicolumn{3}{|c|}{ Mexico, Argentina, Brazil, Chile, Ecuador, } \\
\hline Papua New Guinea (crisis) & -0.8114 & 0.7509 \\
\hline Adj. $\mathrm{R}^{2}$ & 5.0 & \\
\hline F-stat & 2.8 & $(0.00)$ \\
\hline Wald-test & 2.9 & $(0.00)$ \\
\hline
\end{tabular}

( Continued) 
TABLE 5. (Continued)

Note: This table reports how disclosed changes in domestic, aggregated foreign and foreign country-specific earnings movements are affecting firms' changes in dividends per share from 1993 to 2010. The table distinguishes between dividend increases and dividend decreases. The following model is used:

$$
\begin{aligned}
\frac{D_{i t}}{P_{i, t-1}}= & \sum_{k} \zeta_{i k} \text { Country }_{k}+\sum_{p} \xi_{i p} \text { Industry }_{p}+\sum_{t} \varsigma_{t} \text { Year }_{t}+\lambda_{1} \frac{\Delta D E_{i t}}{M V_{i t-1}}+ \\
& \lambda_{2} \frac{\Delta D E_{i t}}{M V_{i t-1}} \times \text { Crisis }_{t}+\sum_{j}^{s} \lambda_{j+2} \frac{\Delta F S E_{j i t}}{M V_{i t-1}}+ \\
& \sum_{j} \lambda_{j+2+s} \frac{\Delta F S E_{j i t}}{M V_{i t-1}} \times \text { Crisis }_{t}+\varepsilon_{i, t}
\end{aligned}
$$

where $\Delta D_{i, t}$ is the change in firm i's dividend per share from fiscal year $t-1$ to fiscal year $t$, $P_{i, t-1}$ is firm $i$ 's stock price at the end of the fiscal year $t-1$, Country refers to country of origin dummies equal to one for the proper country of origin of firm $i$, zero otherwise, Industry refers to sector dummies equal to one for the proper industry of firm $i$, zero otherwise, Year refers to the year dummies equal to one for the corresponding year $t$ and zero otherwise, Crisis refers to the crisis dummy equal to 1 if the fiscal year $t$ is between 2007 and 2010 and zero otherwise. $\triangle D E_{i, t}$ is the change in domestic earnings, defined as the change in operating earnings generated in firm $i$ 's home country, from fiscal year $t-1$ to fiscal year $t . \Delta F S E_{i j, t}$ is the change in specific foreign earnings generated in country $j$, defined as the change in operating earnings generated by firm $i$ in country $j$, from fiscal year $t-1$ to fiscal year $t . M V_{i, t-1}$ is the market value of firm $i$ at the end of firm $i$ 's fiscal year $t-1$. The F-stat is a test of the null hypothesis that the earnings coefficients are equal to zero. P-values are provided in parentheses. Wald tests for equality of both domestic and foreign coefficients are provided with the $\mathrm{p}$-value in parentheses.In Panel B, geographic clusters are then formed for countries exhibiting similar effects on dividend changes, for which we do not find statistically different coefficients at the $10 \%$ level. ${ }^{*}, * *, * *$ indicate that the estimated coefficients are statistically different from zero at the $10 \%, 5 \%$ and $1 \%$ level respectively. White's (1980) heteroskedasticity-consistent standard errors are also exhibited.

\section{Concluding remarks}

It is a widely-held belief that firms pay dividends to signal profitability. But how far are managers going in differentially signaling domestic versus foreign earnings information? To what extent are they more - or less - translating the news related to firm performance generated in domestic markets into dividends than they are disseminating the information coming from different types of foreign markets? The present paper constitutes the first study shedding light on firms' 
dividend payout behavior in relation to the huge amount of information contained in segmented foreign country-specific performance disclosures.

The study examines the geographic performance and dividend policy of 283 U.S., Canadian, European, Australian and New Zealand companies. Using this dataset consisting of 1,506 firm-year observations from 1993 to 2006, we thoroughly explore the relationship between dividend changes measures and domestic versus foreign country-specific earnings movements. First, we concentrate on foreign performance shifts in the aggregate and verify how they are affecting firms' dividend behavior compared to domestic earnings changes. For North American and European companies, we do not find supportive evidence of signaling. On the other hand, Australian and New Zealand corporations - both characterized by stronger payouts - are found to exhibit significant responses to both domestic and foreign earnings.

When focusing on the dividend policy response to performance news generated by foreign country-specific operations, four key points emerge from the empirical findings: (i) dividend increases appear to signal favorable information about performance, while there is no evidence that dividend decreases contain information about changes in earnings. (ii) The positive relationship between foreign earnings growth rates and dividend movements is mainly driven by performance shifts happening in emerging markets and Asian Pacific markets. Managers do not seem feel compelled to signal earnings from North America and Western Europe, since investors can reliably verify the earnings disclosures originating from these areas for themselves - no signal through dividends seems to be needed. (iii) Managers seem to be more confident in the persistence of earnings accruals generated in less risky - more predictable - Asian countries than they are relying on the persistence of positive earnings news coming from riskier - more volatile - countries. Managers appear to be more doubtful towards the continuity of positive performance changes related to operations in these vulnerable, less stable and less regulated markets. Given the higher volatility of earnings movements in these 'risky' emerging countries, they hesitate to convey too strong information signals about positive performance shifts generated in these markets. Positive profitability shocks generated in these markets are, thus, positive but significantly lower.

Accepted by: Prof. P. Theodossiou, Editor-in-Chief, May 2014 


\section{References}

Aggarwal, R., and Aung Kyaw, N. 2010. Capital structure, dividend policy and multinationality. Theory versus empirical evidence. International Review of Financial Analysis 19(2): 140-150.

Aleksanyan, M., and Danbolt, J. 2005. Pricing and value relevance of geographical earnings: empirical evidence from the UK. Working paper. University of Glasgow.

Alzahrani, M., and Lasfer, M. 2009. The impact of taxation on dividends: a cross-country analysis. Working paper. Cass Business School.

Ambarish, R.; John, K.; and Willams, J. 1987. Efficient signaling with dividends and investments. Journal of Finance 42: 321-343.

Amihud, Y., and Murgia, M. 1997. Dividends, taxes, and signaling: evidence from Germany. Journal of Finance 52: 397-408.

Araujo, A.; Moreira, H.; and Tsuchida, M. 2011. Do dividend changes signal future earnings? Journal of Financial Intermediation 20: 117-134.

Baker, M., and Wurgler, J. 2004. A catering theory of dividends. Journal of Finance 59: 1125-1165.

Bar-Yosef, S., and Huffman, L. 1986. The information content of dividends: a signaling approach. Journal of Financial and Quantitative Analysis 21: $47-58$.

Bhattacharya, S. 1979. Imperfect information, dividend policy and 'the bird in the hand fallacy. Bell Journal of Economics 10: 259-270.

Bhattacharya, S. 1980. Nondissipative signaling structures and dividend policy. Quarterly Journal of Economics 95: 1-24.

Benartzi, S.; Michaely, R.; and Thaler, R. 1997. Do changes in dividends signal the future or the past? Journal of Finance 52: 1007-1034.

Bernhardt, D.; Douglas, A.; and Robertson, F. 2005. Testing dividend signalling models. Journal of Empirical Finance 12: 77-98.

Bernheim, B. 1991. Tax policy and the dividend puzzle. Rand Journal of Economics 22: 455-476.

Boatsman, J.; Behn, B.; and Patz D. 1993. A test of the use of geographical segment disclosures. Journal of Accounting Research 31: 46-64.

Bodnar, G.M.; Hwang, L.; and Weintrop, J. 2003. The value relevance of foreign income: an Australian, Canadian, and British comparison. Journal of International Financial Management and Accounting 14: 171-193.

Bodnar, G., and Weintrop, J. 1997. The valuation of foreign income of U.S. multinational firms: A growth opportunities perspective. Journal of Accounting and Economics 24: 69-98.

Bozos, K.; Nikolopoulos, K.; and Ramgandhi, G. 2011. Dividend signaling under economic adversity: Evidence from the London Stock Exchange. International Review of Financial Analysis 20: 364-374.

Brav, A.; Graham, J.; Harvey, C.; and Michaely, R. 2005. Payout policy in the 21 st century. Journal of Financial Economics 77: 483-527. 
Brockman, P., and Unlu, E. 2011. Earned/contributed capital, dividend policy, and disclosure quality: An international study. Journal of Banking and Finance 35: 1610-1625.

Brook, Y.; Charlton, W.; and Hendershott, R. 1998. Do firms use dividends to signal large future cash flow increases? Financial Management 27: 46-57.

Carroll, T. 1995. The information content of quarterly dividend changes. Journal of Accounting, Auditing, and Finance 10: 293-317.

Christophe, S. 2002. The value of U.S. MNC earnings changes from foreign and domestic operations. Journal of Business 75: 67-93.

Christophe, S. 1997. Hysteresis and the value of the U.S. multinational corporation. Journal of Business 70: 435-462.

Christophe, S., and Pfeiffer, R. 2002. The valuation of MNC international operations during the 1990s. Review of Quantitative Finance and Accounting 18: 119-138.

DeAngelo,H.; DeAngelo, L.; and Skinner, D. 1996. Reversal of fortune. Dividend signaling and the disappearance of sustained earnings growth. Journal of Financial Economics 40: 341-371.

Denis, D.; Denis, D.; and Sarin, A. 1994. The information content of dividend changes. Cash flow signalling, overinvestment, and dividend clienteles. Journal of Financial and Quantitative Analysis 29: 567-587.

Duchin, R.; Ozbas, O.; and Sensoy, B.A. 2010. Costly external finance, corporate investment and the subprime mortgage crisis. Journal of Financial Economics 97: 418-435.

Eades, K. 1982. Empirical evidence on dividends as a signal of firm value. Journal of Financial and Quantitative Analysis 17: 471-500.

Easterbrook, F. 1984. Two agency-cost explanations of dividends. American Economic Review 74: 650-659.

Fuller, K., and Goldstein, M.A. 2011. Do dividends matter more in declining markets? Journal of Corporate Finance 17: 457-473.

Gelb, D. 2000. Corporate signalling with dividends, stock repurchases, and accounting disclosures: an empirical study. Journal of Accounting, Auditing and Finance 15: 99-120.

Grullon, G.; Michaely, R.; Benartzi, S.; and Thaler, R. 2005. Dividend changes do not signal changes in future profitability. Journal of Business 78: $1659-1682$.

Guay, W., and Harford, J. 2000. The cash-flow permanence and information content of dividend increases vs. repurchases. Journal of Financial Economics 57: 385-415.

Healey, P.M., and Palepu, K.G. 1988. Earnings information conveyed by dividend initiations and omissions. Journal of Financial Economics 21: 149-175.

Herrmann, D., and Thomas, W. 2000. An analysis of segment disclosures under SFAS no 131 and SFAS no 14. Accounting Horizons 5: 287-302. 
Hines, J. 1996. Dividends and profits: some unsubtle foreign influences. Journal of Finance 51: 661-689.

Ho, H. 2003. Dividend policies in Australia and Japan. International Advances in Economic Research 9 (2): 91-100.

Hope, O.; Kang, T.; Thomas, A. B.; and Vasvari, F. 2009. The effects of SFAS 131 geographic segments disclosures on the valuation of foreign earnings. Journal of International Business Studies 40(3): 421-443.

Hsu, J.; Wang, X.; and Wu, C. 1998. The role of earnings information in corporate dividend decisions. Management Science 44: 173-191.

Iatridis, G. 2010. International Financial Reporting Standards and the quality of financial statement information. International Review of Financial Analysis 19(3): 193-204.

Iatridis, G. 2008. Accounting disclosure and firms' financial attributes: Evidence from the UK stock market. International Review of Financial Analysis 17(2): 219-241.

Jensen, M. 1986. Agency costs of free cash flow, corporate finance, and takeovers. American Economic Review 76: 323-329.

John, K., and Williams, J. 1985, Dividends, dilution and taxes: A signaling equilibrium. Journal of Finance 40: 1053-1070.

Kalay, A. 1980. Signalling, information content, and the reluctance to cut dividends. Journal of Financial and Quantitative Analysis 1: 855-869.

Khurana, I. K.; Pereira, R.; and Raman, K.K. 2003. Does analyst behavior explain market mispricing of foreign earnings for U.S. multinational firms? Journal of Accounting, Auditing and Finance 18(4): 453-478.

Koch, A., and Sun, A. 2004. Dividend changes and the persistence of past earnings changes. Journal of Finance 59: 2093-2116.

Lie, E., and Lie, H. 1999. The role of personal taxes in corporate decisions: an empirical analysis of share repurchases and dividends. Journal of Financial and Quantitative Analysis 34: 533-552.

Megginson, W., and Von Eije, H. 2008. Dividends and share repurchases in the European Union. Journal of Financial Economics 89: 347-374.

Miller, M.H., and Rock, K. 1985. Dividend policy under asymmetric information. Journal of Finance 40: 1031-1052.

Moser, W. 2007. The effect of shareholder taxes on corporate payout policies. Journal of Financial and Quantitative Analysis 42: 991-1020.

Mougou,, M., and Rao, R. 2003. The information signaling hypothesis of dividends: evidence from cointegration and causality tests. Journal of Business Finance \& Accounting 30: 441-478.

Nichols, D.; Street, D.; and Gray, S. 2000. Geographic segment disclosures in the United States: reporting practices enter a new area. Journal of International Accounting, Auditing, and Taxation 9: 59-82.

Nissim, D., and Ziv, A. 2001. Dividend changes and future profitability. Journal of Finance 56: 2111-2133. 
Nwaeze, E.T. 1998. Public utility regulation in the US and asymmetric return responses to positive and negative abnormal earnings. Multinational Finance Journal 2: 269-293.

Penman, S. 1983. The predictive content of earnings forecasts and dividends. Journal of Finance 38: 1181-1199.

Radebaugh, L.; Gray, S.; and Black, E. 2006. International Accounting and Multinational Enterprises. 6th Edition, John Wiley and Sons.

Ramakrishnan, R.T.S., and Thomas, J.K. 1998. Valuation of permanent, transitory and price-irrelevant components of reported earnings. Journal of Accounting, Auditing and Finance 13: 301-336.

Riding, A. 1984. The information content of dividends: another test. Journal of Business Finance \& Accounting 11: 163-176.

Ross, S. 1977. The determination of financial structure: the incentive signaling approach. Bell Journal of Economics 8: 23-40.

Sant, R., and Cowan, A.R. 1994. Do dividends signal earnings? The case of omitted dividends. Journal of Banking and Finance 18: 1113-1133.

Thomas, W. 2000. The value-relevance of geographic segment earnings disclosures under SFAS 14. Journal of International Financial Management and Accounting 11: 133-155.

Travlos, N.; Trigeorgis, L.; and Vafeas, N. 2001. Shareholderwealth effects of divindend policy changes in an emerging stock market: The case of Cyprus. Multinational Finance Journal 5: 87-112.

Tucker, J.W., and Zarowin, P.A. 2006. Does income smoothing improve earnings informativeness? The Accounting Review 81: 251-270.

Watts, R. 1973. The informational content of dividends. Journal of Business 46: 191-211.

White, H. 1980. A heteroskedasticity-consistent covariance matrix estimator and a direct test for heteroskedasticity. Econometrica 48: 817-838.

Yoon, P., and Starks, L. 1995. Signaling, Investment opportunities, and dividend announcements. Review of Financial Studies 8: 995-1018. 